Copyright (C) 2018 by Academic Publishing House Researcher

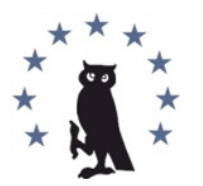

Published in the Russian Federation

European Researcher. Series A

Has been issued since 2010.

ISSN 2219-8229

E-ISSN 2224-0136

2018, 9(3): 227-234

DOI: $10.13187 / \mathrm{er} .2018 .3 .227$

www.erjournal.ru

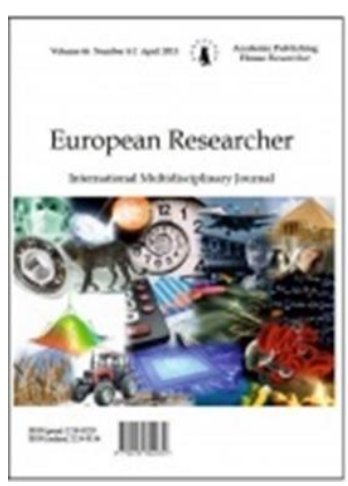

\title{
Motivation of Employees in Hotel Patria (Serbia)
}

\author{
Vladan Jonić a, * \\ a Singidunum University, Belgrade, Serbia
}

\begin{abstract}
The main goal of this research is to determine the motivational factors affecting employees at the Patria Hotel in Subotica (Serbia). In order to achieve this we conducted a survey in the hotel. The managers in each department distributed the surveys to the employees. All employees were randomly selected. Based on 50 surveyed employees who completed the questionnaire, our results revealed that there are significant differences between men and women when it comes to reasons why they chose this hotel as their workplace. Results further reveal significant differences between genders when it comes to main motivational factors in the workplace.
\end{abstract}

Keywords: motivation, hotel, employees, Serbia.

\section{Introduction}

The hotel industry is a significant part of the tourism industry world wide and its employees play a key role in delivering the service to customers. The motivation of employees, whether professional, skilled or unskilled, is a major issue in all service organizations. For the hotel industry, employee motivation is a major issue. It is a challenge for the hotel industry to motivate employees, to stay on the job, and to offer the efficient, good service which customers expect.

Hotel Patria is placed beside the main square of the city. A decade ago it was the only hotel in Subotica, but today you can find a lot of new young and modern hotels or motels too. It is placed between the rail and bus station. There are a lot of well-known buildings and monuments and business centers very close to the hotel. The Patria Hotel consists of 141 rooms, a restaurant, a caffe bar, a nightclub, an aperitif bar, a hairdresser, a sauna, a rent-a-car agency, boutiques and a summer garden. All rooms contain air conditioning, mini bar, LCD TV, Cable TV with 68 channels, ADSL high speed internet, direct telephone, and card access to rooms. The hotel also has a conference room with capacity up to 280 seats, air-conditioned and equipped with modern equipment: projector, canvas, flip chart, sound, chair with the addition of notes and telephone line. Also, the Hotel offers press room, seating people is ideal for press conferences. The fitness center is equipped with the latest equipment, Technogym multi-functional machines, free weights, cardio program. Next to the fitness center, the hotel offers a swimming pool, sauna, massage etc.

Because of the high turnover and high absenteeism within the hospitality industry service, managers now realize the importance of employee motivation to retain quality staffing. When employees maintain a high level of motivation, quality services will result. The purpose of this study was to assess the motivational factors of employees at the Patria Hotel in Subotica, Serbia.

\footnotetext{
* Corresponding author

E-mail addresses: vladanjonic1985@gmail.com (V. Jonić)
} 
Three objectives were included in this study: The first was to determine the reasons employees choose to work at the Patria Hotel. The second was to determine the workplace motivational factors for hotel employees and the third one was to investigate motivational differences between genders at the Patria Hotel.

\section{Literature Review}

Motivation in simple terms may be understood as the set of forces that cause people to behave in certain ways. Many people know motivation as the driving force behind an action. This may be the simplest definition of motivation. Motivation can be considered the state of having encouragement to do something.

In any organization a motivated employee generally is more quality oriented. Highly motivated employees are more productive. Motivated employees are needed in our rapidly changing workplaces. Motivated employees help organizations to survive. To be effective, management need to understand what motivates employees within the context of the roles they perform. For the hotel industry, employee motivation is a major issue. It is a challenge for the management of the hotel industry to motivate employees, to stay on the job and to offer the efficient, good service which customers expect (Cheng, 1995).

\section{Motivation theories}

Five major approaches of motivation are Maslow's need-hierarchy theory, Herzberg's twofactor theory, Vroom's expectancy theory, Adams' equity theory, and Skinner's reinforcement theory.

According to Maslow, employees have five levels of needs (Maslow, 1943): physiological, safety, social, ego, and self-actualizing. Maslow argued that lower level needs had to be satisfied before the next higher level need would motivate employees.

Herzberg's categorized motivation into two factors: motivators and hygiene (Herzberg et al., 1959). Motivator or intrinsic factors, such as achievement and recognition, produce job satisfaction. Hygiene or extrinsic factors, such as pay and job security, produce job dissatisfaction.

Vroom's theory is based on the belief that employees efforts will lead to performance and performance will lead to rewards (Vroom, 1964). Rewards may be either positive or negative. The more positive the reward the more likely the employee will be highly motivated. Conversely, the more negative the reward the less likely the employee will be motivated.

Adams' theory states that employees struggle for equity between themselves and other employees. Equity is achieved when the ratio of employee outcomes over inputs is equal to other employee outcomes over inputs (Adams, 1965).

Skinner's theory simply states those employees' behaviors that lead to positive outcomes will be repeated and behaviors that lead to negative outcomes will not be repeated (Skinner, 1953). Management should positively reinforce employee behaviors that lead to positive outcomes. Management should negatively reinforce employee behavior that leads to negative outcomes.

\section{Importance of motivation}

Motivation is required for the organizations, because:

- Motivated employees are always looking for better ways to do a job.

- A motivated employee generally is more quality oriented. This is true whether we are talking about a manager spending extra time in handling a restaurant or hotel or an associate taking extra care when arranging a function.

- Highly motivated worker are more productive than apathetic worker.

- Main purpose of motivation is to attract employees not only to join the organizations but also to remain in it.

- Motivated employees perform the tasks in a dependable manner.

\section{Some of the motivational factors for hotel employees}

There are many motivational factors which can be used or are using to motivate the employees: 


\section{Communication}

Within a hotel organization, communication is utmost important for passing information from one individual or group to another. It can be in different ways such as verbal, nonverbal, upward, and downward. Lack of good communication causes low productivity, poor service, and increased costs (Drummond, 1990).

Communication is one of many factors to motivate employees into a cohesive working module which results in objectives being achieved (Morgan, 1990).

\section{Training}

Powers and Barrows (1999) noted how training becomes an important activity for any hotel organization. Training provides on-the-job experiences and information that help employees become more proficient or qualified at a task at their current jobs. A well trained employee results in a reduction of costs, stress, turnover, and absenteeism and a corresponding increase in efficiency and customer satisfaction (Mill, 1998). Steven Hickey, senior vice president of T.G.I Friday's, noted "training is probably the most important aspect of reduced turnover because it minimizes mistakes and that minimizes a lot of reasons for turnover" (Powers, Barrows, 1999).

\section{Wages and Salaries}

Salaries are the most obvious motivational factor when it comes to our jobs. Employees constantly compete for positions that offer the quickest, most easily accessible reward. Sometimes, many other motivational factors may sacrificed by employees to attain job satisfaction. That is why whenever any associate got good pay in another hotel or another service sector he moves.

Pay, is a major consideration in human resource management because it provides employees with a tangible reward for their services (Bohlander et al., 2001). Stone (1982) indicated that people are motivated by money for many different reasons. The need to fulfill the basic necessities of life motivates most people. Some people think of money as instrumental motivational factor, to satisfying non economic needs such as power, status and affiliations with desired groups. Money is often viewed as a symbol of personal success and achievement.

\section{Fringe Benefits}

Fringe benefits are additional to wages of workplace compensation. The fringe benefits for the workers in hotel organizations help the operation by having a positive, motivating work climate, increases in productivity, sales, profitability, excellent quality and cost control.

Money is an important factor to motivate employees but today, fringe benefits become equal to money as an important role to motivate employees. Following are the different fringe benefits given in hotel organization to its employees:

- Health insurance: Health insurance is the most common benefit in the hotel industry.

- Leave Travel Allowances: Mostly Hotel organization provide LTA (Leave Travel Allowances) to its employees, in which they are given vacations with pay and some extra amount in the form of travel allowance. It is generally agreed that vacations are essential to the well being of an employee. This benefit also favors employees who need extra time to care for their aging parents or those simply wishing to spend their time with their family.

- Meals: In many hospitality operations, employees receive one free meal per daily shift and an unlimited amount of coffee and soft drinks. At Subway, for example, employees can eat for free in the company's cafeteria; most hotels also serve meals in the employees' cafeteria and do not permit employees to use food and beverage outlets at their place of employment (Jerris, 1999).

- Uniform: Every hotel organization provides two set of uniform, which are laundered in hotel itself and provide to employees on rotation basis, i.e. washed against soiled uniform.

Good Working Environment

Wheelhouse (1989) noted that the working environment can often be a cause of low productivity. Employees need adequate equipment, space, heating, lighting and ventilation. Color also has a significant impact on the work environment. Restrooms and lockers need to be clean, secure, and well maintained. The food provided should be the same for line employees as for the managers. Managers, including top executives, should be expected to eat at the cafeteria except when entertaining. If it's not good enough for managers, it should be consider not good enough for line employees. Therefore, Cheng (1995) noted that a good working environment means employees want the same conditions in their work as similar to the management. They need challenge, 
support from superiors, a quality workplace, friendly co-workers and respect. To have a good working environment, management has to trust and value to its employees.

\section{Methodology}

The purpose of this study was to research the motivational factors that affect employees in the Patria Hotel in Subotica, Serbia. This was done by contacting the hotel director and asking for his approval to distribute a questionnaire to the managers in each department of the hotel. Then the managers in each department distributed the surveys to the employees. All employees were randomly selected. The managers of each department collected the completed questionnaires and brought them back to the researcher. The 50 employees who completed the survey in this study consisted of 24 males and 26 females. The survey was distributed between April $7^{\text {th }}-18^{\text {th }}$ to the employees.

It addressed two major concerns of this research: the reason for choosing to work in the Patria Hotel and motivational factors that make employees perform their jobs the best. Also, the questionnaire was based on a previous study conducted by Cheng (1995). The questionnaire consisted of two parts. The first was designed to collect respondents' demographic data and the second part was designed to gather the respondents' motivation characteristics. The questions include: the reason for working in the Patria Hotel and the most desired motivational factors.

The second part of the questionnaire can answer the objectives of this study regarding the reasons people choose to work at the hotel and to find out the most sognificant motivational factors for employees. In this part of the questionnaire, respondents were asked to rate the motivation factors that they like on a five-point Likert scale $(1=$ less important, $2=$ somewhat important, $3=$ important, 4 = very important, $5=$ the most important).

For data analysis we used the Statistical Program for the Social Science (SPSS). The analysis of the survey results combined with the statistical applications allowed us to draw conclusions regarding to the objectives of the study.

\section{Results and discussion}

This chapter presents the analysis of the data collected by the previously mentioned methodology.

\section{Respondent profile}

The participants were asked to provide information about demographic data such as gender, age, position and working status. The results from 50 employees showed that: twenty four (48.6\%) were male and twenty six (51.4 \%) were female.

In question No. 2 fifty respondents indicated that 21 were from 18 to 28 years old. Fifteen of 50 respondents were from 29 to 39 years old. Four were from 40 to 50 years old. And 10 of 50 respondents were over 50 years old.

Out of 50 respondents, $42.4 \%$ worked in room positions, $31.6 \%$ of the respondents worked in food position. $26 \%$ of the respondents worked in other positions

The results also showed that 39 respondents were full time employees and 11 were part time employees.

In question No. 5, Respondents indicated their working period in the hospitality industry. Seven respondents have been working in the hospitality industry less than one year. Nine respondents have been working in the hospitality industry for one to three years. Ten respondents have been working in the hospitality industry for four to six years. And twenty four respondents have been working in the hospitality industry for more than six years. This data shows that most of employees in the Patria Hotel have been working in the hospitality industry for a long time.

Question No. 6 indicated nine respondents have been working in the Patria Hotel less than one year. Seventeen respondents have been working in the Patria Hotel for one to three years. Nine respondents have been working in the Patria Hotel for four to six years. And sixteen respondents have been working in the Patria Hotel more than six years.

\section{Reasons for Choosing a Career in the Patria Hotel}

The second part of the questionnaire tried to determine the reasons employees chose to work at the Patria Hotel. Because of the importance of the reasons listed in the question, the Likert scale was used for answering ( $1=$ less important, $2=$ somewhat important, $3=$ important, $4=$ very 
important, 5 = the most important). Thus, this question was analyzed by using the mean to identify the rank of each reason.

The results show that, "Class of hotel" was ranked first (3.90), "Interesting job" was ranked second (3.76), "Salary" was ranked third (3.59), "Flexible hours" was ranked fourth (3.51), "Fringe benefits and Close to my home" were ranked fifth in the same level (3.23), "Opportunity to meet people" was ranked sixth (3.11), "Become manager in this field" was ranked seventh (2.39), "Friends work here" was ranked eighth (1.99), "Could not find any other job" was ranked ninth (1.58), and "Somebody in my family works here" was ranked tenth (1.46).

Table 1. The reason for choosing a career in the Patria Hotel $(n=50)$

\begin{tabular}{cccc}
\hline Reasons & Mean Ranking & Standard Deviation & Ranking \\
Class of hotel & 3.90 & 1.22 & 1 \\
Interesting job & 3.76 & 1.10 & 2 \\
Salary & 3.59 & .94 & 3 \\
Flexible hours & 3.51 & 1.05 & 4 \\
Fringe benefits & 3.23 & 1.11 & 5 \\
Close to my home & 3.23 & 1.34 & 6 \\
Opportunity to meet & 3.11 & 1.27 & 7 \\
$\quad$ people & & & 8 \\
Become managers in & 2.39 & 1.47 & 9 \\
$\quad$ this field & 1.99 & 1.22 & 10 \\
Friends work here & 1.58 & 1.21 & \\
Could not find any & & & \\
$\quad$ other job & 1.46 & 1.09 & \\
Somebody in my & & & \\
family works here & & &
\end{tabular}

\section{The most significant motivation factors in the Patria Hotel}

The third part of the questionnaire tried to determine the workplace motivational factors for the Patria Hotel employees. Because of the importance of the factors listed in this part of the questionnaire, the Likert scale was used for answering $(1=$ less important, 2 = somewhat important, 3 = important, 4 = very important, 5 = the most important). Thus, this question was analyzed by using the mean to identify the rank of each reason.

The results show that "Salary" was ranked first (3.75), "Job security" was ranked second (3.74), "Interesting job" was ranked third (3.71), "Working environment" was ranked fourth (3.70), "Co-workers" was ranked fifth (3.67), "Loyalty to employees" was ranked sixth (3.63), "Part of the team" was ranked seventh (3.52), "Flexible hours" was ranked eighth (3.39), "Fringe benefits" was ranked ninth (3.26), "Empowerment" was ranked tenth (3.17), "Opportunity for advancement" was ranked $11^{\text {th }}$ (3.16), and the last one is "Training" (3.14).

\section{The motivational differences between genders at the Patria Hotel}

The goal of the final part of the questionnaire was to investigate motivational differences between genders at the Patria Hotel. In this objective, we analyzed data by using the mean to identify different motivation factors between genders. Table 2 below shows the data of motivational differences between males and females in order to identify the rank of each motivational factor.

Table 2. Male and Female Motivation Factors: Side by Side Comparison

\begin{tabular}{ccc}
\hline Work Motivation & Male & Ranking \\
& Female \\
\hline Salary & 1 & 4 \\
Job security & 2 & 5 \\
Loyalty to employees & 3 & 7 \\
Co-workers & 4 & 3 \\
Working environment & 5 & 2 \\
\hline
\end{tabular}




\begin{tabular}{ccc}
\hline Interesting job & 6 & 1 \\
Fringe benefits & 7 & 11 \\
Flexible hours & 8 & 8 \\
Part of team & 8 & 6 \\
Training & 9 & 10 \\
Opportunity for advancement & 10 & 9 \\
Empowerment & 11 & 8 \\
\hline
\end{tabular}

The study results indicated that the employees chose to work at the Patria Hotel because of (1) Class of hotel, (2) Interesting job, (3) Good pay.

The most significant motivation factors regarding the Patria Hotel employees are (1) Good pay, (2) Job security, (3) Interesting job.

Overall, males' and females' ratings were different. Male concerns were about salary first, then job security and loyalty to the employees. Female concerns about an interesting job were first, then working environment and co-workers.

This study provides information which could benefit the human resources department in better understanding the needs of hotel workers. The human resource director could consider and develop the following factors to respond to the needs of his employees:

- To provide the right motivational factors to employees, the human resources director should evaluate the needs of employees every year.

- Management should be concerned about the basic need of employees first because the results of this study showed that salary and job security were the first and second rank of work factors for employees.

- Management can make a job more interesting by using job design such as job rotation or job characteristics, because an interesting job is in the first rank for a female motivational factors.

- Managers of each department should develop a family atmosphere within the hotel.

\section{Conclusion}

The purpose of this study was to research employees' attitudes toward motivation and discover the reasons behind why workers chose to work at the Patria Hotel. Moreover, the aim was also to help hotel management, especially human resource managers to better understand the employees' motivational factors, therefore reducing the turnover and absenteeism through an efficient motivational approach.

Our results show that the main reason people chose a career in the Patria Hotel was "Class of hotel", followed by the fact that it was an "Interesting job". In their research, Jerald and Robert (1997) revealed that motivation can be enhanced by making jobs more appealing to people. Today's organizational scientists have discovered many ways of creating jobs that can not only be performed very efficiently, but also are very pleasant and enjoyable. These include job enlargement, job enrichment and job characteristics model. The former is one of the first modern approaches to redesigning jobs, suggesting that such unwanted could be minimized by having people perform an increased number of different tasks all at the same level. Job enrichment provides workers not only more tasks to do, but also more tasks to do at a higher level of skill and responsibility.

The third reason was salary. The Patria Hotel provides higher salaries than other hotels of in the city. Wheelhouse (1989) stated that job salary must be an important goal for the worker as well as one of the biggest motivators. The stronger a worker wants more money, his efficeincy and production will also improve.

One of our objectives was also to learn what motivates employees at the Patria Hotel to perform the best on their jobs. Our results showed that the best motivational factor for workers was "Salary". In his study, Wheelhouse (1989) revealed that the main goals of the salary program are to help companies attract and keep qualified people, provide them equal pay for equal work, reward good performance and maintain a cost parity with other competitors in the same branch of business. Therefore, the human resource manager should carefully consider higher salaries as a main motivator. 
The second placed motivator was "Job security". According to Maslow's Hierarchy of Needs, after being satisfied by the first level, such as money, they will go to the next level, the need for security. Therefore, Maslow's theory can exemplify the motivational factors of the Patria Hotel worker because the primary factor the worker chose was salary, and job security was the second factor. Furthermore, research of Daschler and Ninemeier (1989) about strategies for employees' motivation revealed that most workers look for job security assurance. Thus, one of the the main factors that should concern the hotel management is job security.

The third motivator was "Interesting Job". As already mentioned, an interesting job is a motivation factor that can minimize the turnover and absenteeism rate in every organization. Research conducted by Daschler and Ninemeier (1989) about strategies to improve workers' motivation revealed that other factors that motivate workers are dynamic, challenging jobs, tasks that yield a sense of personal accomplishment, increased responsibility and the opportunity to advance in the workplace. Several other factors that are positive for employees are job rotation, job enlargement and job enrichment. Jerald and Robert (1997) reviewed Frederick W. Taylor's book about treating people like machines often meant having them engage in repetitive movements which they found highly routine and monotonous. After a while, people became bored with such jobs and frequently quit. Therefore, every organization should find several ways of designing jobs to keep good workers with the organizations as long as possible. One of those ways is certainly job rotation.

According to our research results, the main motivation factors of employees in the Patria Hotel are: good salary and job security. Therefore, hotel management should do their best to meet the needs of their workers even though they require different motivators because they come from different backgrounds. People come from different backgrounds with differents experience, education and family so they require different things. Hotel managers need to make an effort to adjust to these differences in the best possible way. Motivational factors can vary in each hotel and each period. Human resources department should evaluate the employees' needs every year.

Review of the work motivation analysis shows a significant difference in male ranking and female ranking. The male ranking had "Salary" as the first one and "Job security" second and "Loyalty to employees" third. Meanwhile, the female ranking had "Interesting job" as the first one, "Working environment" second and "Co-workers" as the third one.

According to Simons and Enz (1995), there is no difference in motivational factors by gender. Our research results show that this is not always the case. Also, Daschler and Ninemeier (1989) stated in the strategies of employees' motivation that employees are individuals. Everybody comes from a different background, experience, education and family so they need different things. Therefore, motivation is a personal, individual concept that depends on the situation at that moment and the background of each person.

\section{References}

Cheng, 1995 - Cheng, H. (1995). Assessing The Importance of Employee Motivation in the Hotel Industry in Taipei, Taiwan. Unpublished master's thesis, University of Wisconsin-Stout, Menomonie, Wisconsin, United States.

Maslow, 1943 - Maslow, A.H. (1943). A Theory of Human Motivation. Psychological Review, 50, 370-396.

Herzberg et al., 1959 - Herzberg, F., Mausner, B., Snyderman, B.B. (1959). The Motivation to Work. John Wiley. New York.

Vroom, 1964 - Vroom, V.H. (1964). Work and motivation. New York: Wiley, 331 p.

Adams, 1965 - Adams, J.S. (1965). Inequity in social exchange. In L. Berkowitz (Ed.), Advances in experimental social psychology, Vol. 2, pp. 267-299. New York: Academic Press.

Skinner, 1953 - Skinner, B.F. (1953). Science and Human Behavior. New York: Macmillan.

Drummond, 1990 - Drummond, K.E. (1990). Human Resource Management for the Hospitality Industry. New York, NY: Van Nostrand Reinhold.

Morgan, 1990 - Morgan, W.J. (1990). Hospitality Personnel Management. Boston, MA: CBI Publishing Company, Inc.

Powers, Barrows, 1999 - Powers, T., Barrows, C.W. (1999). Introduction to Management in the Hospitality Industry. New York, NY: John Wiley and Sons, Inc.

Mill, 1998 - Mill, R.C. (1998). Restaurant Management Customer, Operation, and Employees. Upper Saddle River, NJ: Prentice Hall. 
Bohlander et al., 2001 - Bohlander, G., Snell, S., Sherman, A. (2001). Managing Human Resources. Cincinnati, OH: South-Western College Publishing.

Stone, 1982 - Stone, T.H. (1982). Understanding Personel Management. New York, NY: CBS College Publishing.

Jerris, 1999 - Jerris, A.L. (1999). Human Resource Management for Hospitality. Upper Saddle River, NJ: Prentice-Hall, Inc.

Wheelhouse, 1989 - Wheelhouse, D. (1989). Managing Human Resources in the Hospitality Industry. East Lansing, MI: Educational Institute American Hotel \& Motel Association.

Jerald, Robert, 1997 - Jerald, G., Robert, A.B. (1997). Behavior in Organizations: Understanding and Managing the Human Side of Work, Upper Saddle River, NJ: Prentice-Hall, Inc.

Daschler, Ninemeier, 1989 - Daschler, P.J., Ninemeier, J.D. (1989). Supervision in the Hospitality Industry. East Lansing, MI: Educational Institute American Hotel \& Motel Association. Simons, Enz, 1995 - Simons, T., Enz, C. (1995). Motivating Hotel Employees. Cornell Hotel and Restaurant Administration Quarterly, 36 (1), 20-27. 